\section{The Peace Zone Concept and its Utility in Nepalese Foreign Policy Uma Kant Sharma}

\section{Introduction}

The independent kingdom of Nepal, which is situated between the two giants countries of China and India extends along the southern slopes of the mighty Himalayas for a length of 550 miles. Lying roughly between the 80 th and 88 th meridians of longitude and 26th and 30 th parallels of latitude, the kingdom resembles in shape a narrow and long rectangle varying in breath from 80 th to 120 miles, while its area is about 55,000 square miles. Serving as the meeting place of two of the world's greatest civilizations - China on the north and India on the south - Nepal has developed an individual culture which dates back to a period earlier than that of Gautam Buddha who was born in Nepal, more than 2500 years ago', (K.P. Malla - 1968) The size of Nepal is smaller on the proportion of 22 fold from India and 65 fold from China.

"Janaki of the Ramayana, Lord Buddha and Sagarmatha (Mount Everest) provide a geographical, historical and cultural frame of reference for Nepal, While they stand out in their supreme sublimity dominating our history and consciousness, they do also define in the more material sense the basic outline of our foreign policy through ages. The great Himalayas which have equally inspired poets and mountaineers and which have also symbolized a hard life for the Nepalese nestling in their laps indicate our position not only in relation to India and China, but also in the whole world. No wonder, they have left an abiding stamp on the character and composition of Nepalese people. "Racially and culturally Nepal represents a creative synthesis which is particularly prominent in the virility of its people and its great artistic monuments." (Khanal Yadunath 1968)

"Nepal's foreign policy and the dynamics of its relationship with neighboring states have been conditioned by a complex of factors, of which the political component is only one of the more important. Nepal's cultural relationship with India and China for instance or its role in the trade and economic system between south and north Asia also is most important aspect of Nepalese foreign policy making. (Rose Leo E. 1971) The foremost objective of foreign policy of any country - big or small, developed or least developed is to preserve and promote its national interest. Although its interpretations may vary from country to country depending on their respective perceptions and capabilities, national interest at the minimum composes the very existence of a nation i.e., its territorial integrity, independence, and national survival ( Prof. K. Khanal 1997).

Since its beginning the principle objective of the foreign policy of Nepal is to safeguard the independence, sovereignty and territorial integrity of the country, to secure the co-operation and goodwill of all the countries of the world in all-sided development of the county and to promote the spirit of friendship with all countries. Since national outlook and interest is at the root of internationalism, Nepal has adopted an independent and neutral approach in the forcign relations in a manner, which suits Nepal's national traditions and realities. And since the motive force behind this policy is to secure a good opportunity for national prosperity befitting the aspirations of the people and country and the necessities imposed by the nuclear age of today. Thus, Nepal has been placing full faith in the principle of non-alignment or neutralism in conjunction with the promotion of friendly goodwill with all countries and the maintenance of the world peace.' (King Mahendra 1960)

Late king Birendra (1983) said - "The fundamental objectives of my government's foreign policy will be to protect and promote the national interests, to play an active role in strengthening the causes of international peace, co-operation and good will, and to consistently endeavor with a view to make Nepal, "A Zone of peace", adhering to the basic ideals of the UN and the principles of non-alignment.

Nepal experimented a number of political systems - Shah monarchical system. Rana Oligarchy, multiparty parliamentary system, Panchayat system and again constitutional monarchy and multiparty parliamentary system after 1990 revolution, but Nepal's aim of her foreign policy has been to protect her sovereignty, integrity and peace and security. Because 'like human beings every nation has to establish relationship with their neighbors as well as others for their survival, security and development.

In the past, Geo-polities played a prominent role in the development of Nepalese foreign policy, symbolized in the concept of "a yam between two rocks". In today's context, it is not geography and politics only but also geography, politics and economic policy that are playing the determining role. The rationalization as well as globalization of economics has led to an increasing emphasis on economic diplomacy. The concept and relevance within south Asia co-operation is also being increasingly acknowledged. Therefore, Nepalese foreign policy is the product of her dynamic growth of past policy such as balance of politics, live and let live, the condition of the land-locked, the least development, will to self-identity, will to unified nationality and unity of diversities as well as a strong unified sountry or national-state.

The situation still can be explained in terms of what B.P. Koirala said "Nepal's situation can be symbolically expressed by a triangle, one point of triangle is the king, another point is foreign powers, and we constituted the third". (Political parties) only by combination of these factors Nepal can survive. King Birendra by a deep consideration declared "A Zone of Peace". By the proposal King Birendra has evoked a favorable response from several friendly countries. Thus the attempt 
to institutionalize peace was in the national interest and not aimed against any particular country. It is pertinent to note that while pursuing the policy of friendship with all and enmity towards none, Nepal has taken a particular care to maintain friendly relations with our neighbors, India and the People's Republic of China. The official visits of their Majesties kings and prime ministers and other leaders in time to time to our friendly countries and Non-aligned summit conferences have greatly advanced the cause of the Non-alignment in this world. Nepal's participation in non-aligned summit conference, carried forward the spirit of the cause of Non alignment in all its aspects. Nepal is now and then advocating the cause of landlocked and under developed countries in various fronts.

\section{Determining Factors of Nepalese Foreign Policy}

What are basic factors to evolve a foreign policy doctrine of a particular country is always a matter of importance. "As a matter of fact, the foreign policy of every country rests on its multiple determination including its historical, traditional, geographical location, national interests, security needs and collective goal. A successful policy of a country is considered a function of a political system in action or of the preferences or conviction of political leaders who carry out its programme, so we can say that every country determines its foreign policy in accordance with its historical and ideological needs in the midst of its surroundings. Nepal's foreign policy also is guided by the same principles of historical \& ideological facts. As a new phase of its policy, it is determinately claiming to be a peaceful country in the world community. Even after the re-establishment of multiparty system it is said - "The foreign policy of Nepal shall be guided by the principles of the united Nations' charter, non-alignment, the Panchsheel, International law and the value of world peace". (The constitution of the Kingdom of Nepal, 1990)

\section{A Short history of Panchasheel or Five Principles of C0-existence}

In the year 1954, the world was in a destructive way, because the outbreak of a global war with dangerous atomic weapons only a matter of time. Due to ideological colonization as super power, America was claiming as a leader of the democratic world. In the mean time Soviet Russia also was claiming the same leadership of another block. Thus both Western \& Socialists blocks were strengthened against each other. In one hand the North Atlantic Treaty Organization (NATO) and the south East Asia Treaty Organization (SEATO) were organized and on the other hand Warsaw and Baghdad pacts were singed. So the world was to be divided into two extreme hostile warring blocks. The condition of that cold war led to the origin of the Panchasheel or Five principles. In fact, it was an attempt to establish peace not as precarious assertion of the will to peace for the sake of peace but the general good of humanity. Although now the world is uni-polar because of the disintegration of former soviet union, the danger of super or regional powers over small developing countries is still a living problem.

Five principles are as follows :

1. Each nation recognizes the freedom of every other nation.

2. There must be no aggression against any nation.
3. There must be no interference by one nation in the affairs of another. 4. There must be mutual respect among nations for each other.

5. There must be peaceful co-existence among nations in spite of ideological differences. These principles are a clear unambiguous and straightforward enunciation of the fundamentals of peace. At any moment the nation recognizes the right of each the fun to live its own way of life and the wrongness of interfering in the other people's affairs. By the way it creates a new climate of peace \& mutual understanding among the nations. That is what Panchasheel is to achieve. It assures other people that we do not seek to interfere in their affairs. It ensures a world wide policy of peace and co-existence. In 1954 Bang dung, a summit conference was held in which Nepal was one of the active participants (Information Dept. 1981)

\section{Nepal's previous role on its foreign policy}

The foundation of Nepal's foreign policy was laid by then King Prithiwi Narayan Shah, the founder of modern Nepal, who used to say the imagery "a yam between two boulders", to suggest the policy to be pursued by the country in its geopolitical context. This basic factor enunciated by King P.N. Shah is the main guiding principle of Nepal's foreign policy.

We are to believe that the Panchaseel or the five principles, to guide the nation's behavior gives a framework which is capable of meeting the challenges passed by time even in the 21 st century.

Basically modern Nepal's foreign policy also is guided by the same principles of Panchasheel as such faith in U.N. Charter, adherence to Non alignment movement, institutionalize the world peace voicing against colonialism and racialism. thus upto the coronation of His Majesty King Birendra, Nepal was achieving non-alignment in the world. Incorporation of the policy objective to work towards making. "Nepal a zone of peace by the basic ideals of the United Nations and principles of nonalignment and to achieve the peace zone proposal" is very important phase in the history of Nepalese foreign policy. (constitutions ...1962)

\section{Historical importance of the Zone of peace}

The zone of peace proposal is one of Late King Biredra's most important foreign policy initiatives after ascending the throne on January 31 st 1972 declaring the proposal he had said - "As heirs to one of the most ancient civilizations in Asia, our natural concem is to preserve our independence - a legacy handed down to us by history. The absence of peace will delay make more difficult and even deform our development. Just as a world without peace will jeopardize our traditional independence (King Birendra 1973). In the other world "if our relations with India have deep and extensive, our rełations with China have been equally close and friendly consistently marked by understanding of each other's problems and aspirations". (Khanal, Yadunath 2025 BS).

Speaking on the policy of Non-alignment he said, "We adhere to the policy of Nonalignment because we believe that it brightens the prospects of peace, we need peace for our security, we need peace for our independence, and we need peace for 
development." (King Birendra 1973) The chicf architect of Nepal's peace zone proposal is Late King Birendra, so, there seems a deeply rooted value insight in the proposal. $\mathrm{He}$, in many international gatherings, had put the point of peace zone proposal. It reflects, moreover, our age old longing to be free from strife and hostilities. For a small developing country like Nepal, nothing is more natural than a deep-rooted aspiration for peace and development embroiled in tension, fear, anxiety or instability regional or intemational at a time when our greatest task is that of economic development for our people.

\section{Renewed concept of peace zone proposal}

From the beginning of the peace zone proposal, some of our friendly neighboring countries did not co-operate to our proposal because they might have some sort of doubt in the proposal. Then foreign minister had outlined the details of the proposal during his address to the Nepal council of world affairs on February 21, 1982 almost seven years after the concept was first enunciated. Those seven obligations of peace zone proposal are as follows : (Information dept. 1982)

1. Nepal will adhere to policy of peace, Non alignment and peaceful co-existence, and will constantly endeavor to develop friendly relations with all countries of the world regardless of their social and political system, and particularly with its neighboring countries, on the basis of equality, respect for each other's independence and sovereignty.

2. Nepal will not resort to the use of force in any way, which might endanger the peace and security of other countries.

3. Nepal will seek peaceful settlement of all disputes between it and other states.

4. Nepal will not interfere in the internal affairs of other states.

5. Nepal will not permit any activities on its soil that hostile to other states, supporting this proposal and in reciprocity. States supporting its proposal will not permit any activities hostile to Nepal.

6. Nepal will continue to honor the obligations of all the existing treaties, which it has concluded with other countries so long as they are not detrimental to national independence.

7. In conformity with its policy of peace and non-alignment, Nepal will not enter into any military alliance, nor will it allow the establishment of any foreign military base on its soil. In reciprocity, other countries supporting this proposal nor will they allow establishment of military base on their soil directed against Nepal. The state shall pursue a policy of making continuous efforts to institutionalize peace for Nepal through international recognition, by promoting co-operative and good relations in the economic social and other spheres on the basis of equality with neighboring and all other countries of the world. (Const..... 1990)

\section{Rejuvenation of Panchasheel - Conclusion}

Nepal had broken its isolated foreign policy after the revolution of 2007. Since then Nepal adhered to the policy of Non alignment because of its belief in mutual understanding of each other's problems and aspirations. Nepal's faith in peaceful coexistence means a continuous struggle against all types of foreign dominations, and interventions. The peaceful co-existence is not possible until and unless all the forms of hegemony and inequalities in the world are abolished. Nepal as an active member of the movement since its beginning believes that it is the best way of overcoming existing disparities in the world and eliminating the causes of crises, instability, tension and use of force in the conflicts in international relations. Nepal supports general and complete disarmament and settlement of disputes through mutual consultations and not by hostilities and confrontations. Nepal is pleading for the fight of every nation to develop its own socio political system independently and free from all outside interferences. So the foreign policy objective of recent Nepal is to obtain the real success of peace and independence. Nepal's right direction of its foreign policy from its independence is to get a maturity in the policy of five principles.

The integrity and relevance of the nonaligned movement still seems very fruitful which depends on our conflicting world. Seven obligations of peace zone proposal and recent economic diplomacy seem to be the latest phase of Nepal's foreign policy of panchasheel. So we can say that it stands for a new order of international relations. Nepal has conceived that - "by definition every non-aligned country is a zone of peace, not only because it has shut its doors to the import of hostilities and the confrontations of others but because that policy permits non aligned countries to strengthen their own internal foundation for peace and to extend the atmosphere of peace into world wideareas through regional and inter-regional understanding and co-operation.

Within the growing framework of international law, Nepal itself has developed numerous contacts with outside world and it is necessary to ensure that there is the fullest awareness among our people of our commitment to moral and political values, which define the moral conscience of mankind today.

An open door foreign policy which we are pursuing today requires an intelligent popular participations and national consensus in its evolution and execution.

A review of our foreign policy during the last 48 years since revolution of 1950 to 2004 will show that we have not only preached but also practiced the co-existence. After 1990 revolution on the foreign policy front we are not able to practice independent foreign policy because of our internal problems.

The present age ( 21 st century) demands that every nation, big or small must draw each other further close together and contribute collectively to the complete welfare of humanity.as a whole. Therefore we must develop good and friendly relations with nations of world without attaching ourselves to any particular power groups. Only such kind of foreign policy alone can serve our welfare. So even now we have to practice to peace zone proposal in our foreign policy as a due practice of peace from our own home. As a matter of fact democratic stability and progress in Nepal largely may depend on her ability to meet the age-old chronic problems of poverty, disease and ignorance as well as ethnical. Political freedom and democracy cannot be made intelligible to the people of Nepal, in fact, until and unless we get higher standards of living and better conditions of life, For this, therefore we need peace and integrity from our own home and country. 
References

His Majesty Government, Ministry of Information 1981, Nepalese Foreign Policy. PP 15-18)

K.P. Malla. 1968. Nepal's Foreign Policy : Issues and options,

Khanal, Yadunath. 1996. Nepal after Democratic Restoration, Kathmandu : Ratna Pustak Bhandar.

Khanal, Yadunath. 2025. Nepal's Foreign Policy, Its Content and Execution, Published by in Panchayat Parichaya (2025 BS by HM Govt. Home Ministry, PP 1-3)

King Birendra. 1973. H.M. Speaks on Foreign Policy, Published by HMG Communication Department.

King Mahendra. 1960. Collections of His Majesty King Mahendra's Declarations, Communication Dept.

Modality of Nepalese Peace Zone Policy. 1982. Nepal's Peace Zone, Proposal by HMG Information Department, PP 3-7.

Phanindra Subha, Nepal Economic Diplomacy : Challenges and Prospects, Institute of Foreign Affair (IFA), Nepal's Foreign Policy; Issues and Options.

Rose Leo. E. 1973. Nepal Strategy for Survival, Delhi : Oxford University Press, PP 229. Roy, C. Macridis (Editor). 1962. The Comparative Study of Foreign Policy, Kenneth W.

Thompson and Roy C. Macridis, PP 21.

The Constitution of the Kingdom of Nepal-1990. (26-5)

The Constitution of Nepal-1962. Published by Information Department, HMG.

**** *

Greeting and Best wishes for Peace, Progress and Prosperity on the Auspicious Occasion of

VIJAYA DASHAMI \& DEEPAWALI-2061

Pro. Bal Krishna Baral BARAL ELECTRIC STORES

Srijana Chowk, Pokhara-8, Nepal Tel. : 061-524546

Dealers of all kinds of electricals goods \& general suppliers.

Greeting and Best wishes for Peace, Progress and Prosperity on the Auspicious Occasion of

VIJAYA DASHAMI \& DEEPAWALI-2061 Evergreen Traders Mahendrapool, Pokhara, Tel. : 061-520128

Fax : 00977-61-520128, E-mail : egf@ cnet.wlink.com.np Hardware, Sanitarywares, Paints, Handtools \& Machinaries. 